\title{
Hawthorn Lace Bug, Corythucha cydoniae (Fitch) (Insecta: Hemiptera: Tingidae) ${ }^{1}$
}

\author{
F.W. Mead ${ }^{2}$
}

\section{Introduction}

The hawthorn lace bug, Corythucha cydoniae (Fitch), selectively attacks a variety of woody, rosaceous plants and can cause severe leaf damage. The principal Florida host is firethorn (Pyracantha coccinea Roemer). Most of the Florida records are from the northern part of the state; elsewhere, it has been reported north to Ontario, Canada, southwest to Mexico, and in much of the U.S. from the Atlantic to the Pacific coast.

\section{Partial Synonymy}

Tingis cydoniae Fitch, 1861

Corythucha arcuata Comstock 1880 (not Say, 1832)

Corythuca arcuata var. crataegi Morrill 1903

Corythucha crataegi Morrill, Osborn \& Drake 1916

Corythucha occidentalis Drake (in Gibson 1918).

\section{Distribution}

Blatchley (1926) had no reports of the hawthorn lace bug south of Maryland, but now several states in the "Deep South" can be added to the known range. The oldest Florida specimen in the Florida State Collection of Arthropods (FSCA) was collected at Riverview, Hillsborough County, Florida, 22-VII-1929, F.W. Walker. Another "old" record is a series of eight specimens taken at Gainesville, Alachua County, Florida, 16-VI-1935, H. \& A.N. Tissot, on Crataegus floridana Sarg., collection no. 7462. This series was determined as $C$. cydoniae in 1954 by R.F. Hussey. With the exception of Hillsborough County, all Florida records are from the northern part. FSCA records include the following Florida counties: Alachua, Baker, Calhoun, Columbia, Duval, Hillsborough, Jackson, Jefferson, and Leon.

\section{Identification}

Corythucha cydoniae is the only lace bug reported as a pest of Pyracantha, according to Drake and Ruhoff (1965). Adults are needed for confirmation since diagnostic keys do not exist for

1. This document is EENY-080, one of a series of Featured Creatures from the Entomology and Nematology Department, Florida Cooperative Extension Service, Institute of Food and Agricultural Sciences, University of Florida. Published: May 1999. This document is also available on Featured Creatures Website at http://creatures.ifas.ufl.edu. Please visit the EDIS Website at http://edis.ifas.ufl.edu. Additional information on these organisms, including many color photographs, is available at the Entomology and Nematology Department WWW site at http://entnemdept.ifas.ufl.edu/. 2. F.W. Mead, Florida Department of Agriculture and Consumer Services, Division of Plant Industry, Gainesville, FL.

The Institute of Food and Agricultural Sciences (IFAS) is an Equal Employment Opportunity - Affirmative Action Employer authorized to provide research, educational information and other services only to individuals and institutions that function without regard to race, creed, color, religion, age, disability, sex, sexual orientation, marital status, national origin, political opinions or affiliations. For information on obtaining other extension publications, contact your county Cooperative Extension Service office. Florida Cooperative Extension Service / Institute of Food and Agricultural Sciences / University of Florida / Larry R. Arrington, Interim Dean 
egg and nymphal stages of $C$. cydoniae and related species. Other hosts of this lace bug are sometimes attacked by similar species; therefore, host identification alone is not adequate for identifying the hawthorn lace bug. Field identification of adults is difficult because thre are several similar species. Specimens are small and pigmentation is variable within a species. The most valuable diagnostic character is the straight hind margin of the apical, elytral crossbar. The following diagnosis (modified from Blatchley 1926) distinguishes C. cydoniae from other species of Corythucha.

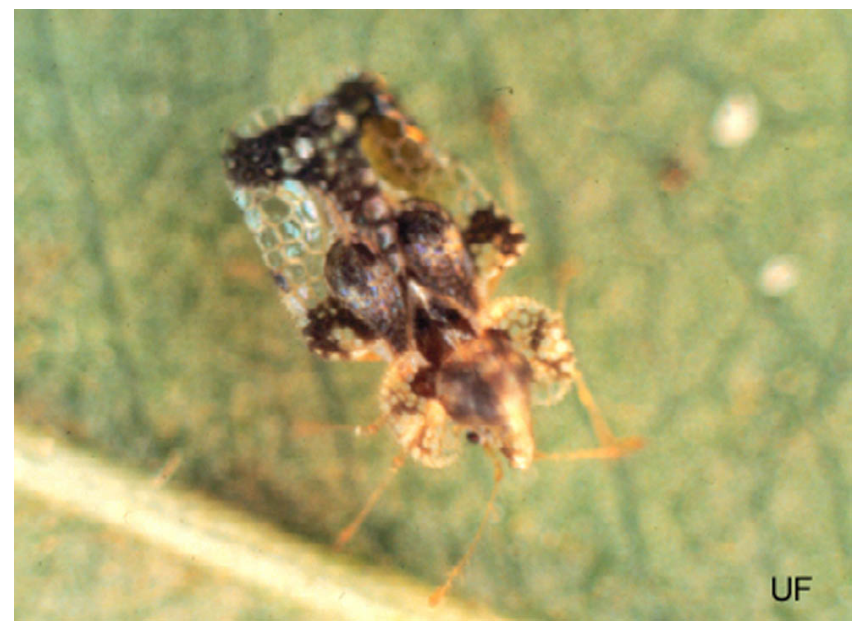

Figure 1. Adult of the hawthorn lace bug, Corythucha cydoniae (Fitch). Credits: University of Florida

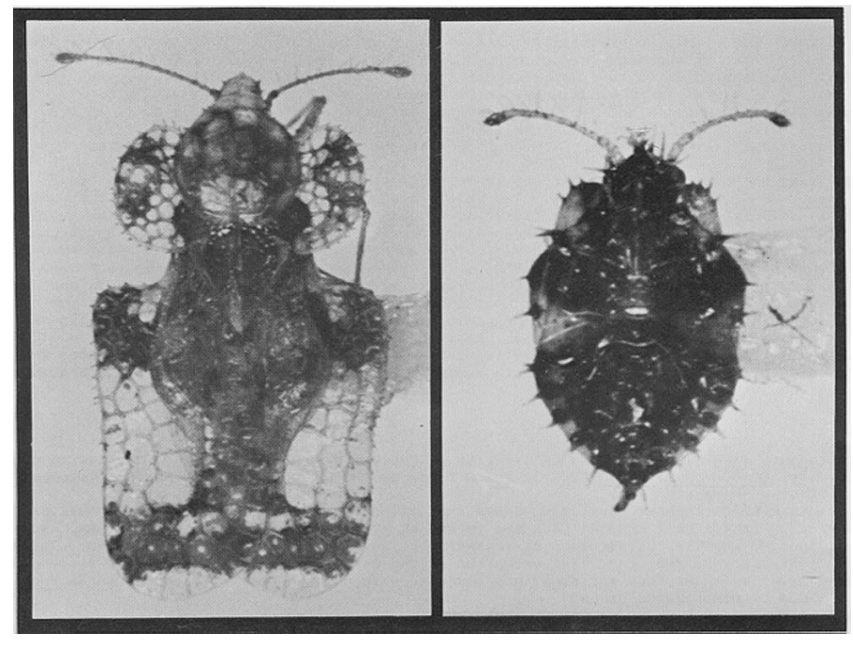

Figure 2. Adult (left) and nymph (right) of the hawthorn lace bug, Corythucha cydoniae (Fitch). Credits: Division of Plant Industry

Crest of hood much elevated, more than twice as high as median carina of pronotum. Costal area of elytra typically with basal and apical crossbars, the space between these mostly pale; front of hood declivent. Costal margins nearly straight, very slightly concave; outer half of each paranotum with a large dark brown spot or stripe, the stripe often interrupted with pale cells, thus forming two spots on each paranotum; 3.0 to $3.5 \mathrm{~mm}$ long, 1.5 to $2.0 \mathrm{~mm}$ wide. The external male and female genitalia have diagnostic characters, but require microscopic examination (Bailey 1951, Feldman and Bailey 1953).

\section{Life History}

The earliest seasonal Florida record in the FSCA is 2 June at Jackson County (a series of adults collected on Crataegus by R.F. Hussey in 1955). The latest record is 25 November (a series of adults collected by me on Pyracantha at Gainesville in 1955). There are several records for June, July, September, and October. There are only two November records and one for August. Nymphs have been reported as early as 7 June and as late as 10 October. Bailey (1951) reviewed existing life history information and added considerable research of his own under New England conditions. He found that the life cycle takes five to seven weeks, depending on the weather, and there was only one full generation per year. Various authors have reported that overwintering is accomplished by adults under leaves, loose bark, sticks and stones. Bailey (1959) added more host and distribution data. Scott (1960) mentioned that it may overwinter in the egg or adult stage (special reference to North Carolina). Sailer (1945) reported that an adult bit his arm six times in approximately 17 minutes, resulting in a reddened square inch of forearm. An itching sensation resulted, but all irritation and evidence of the bites were gone by the next morning. Sailer added that it is common knowledge that Hemiptera will attempt to thrust their mouthparts into any surface upon which they alight, but this type of annoyance is very unusual.

\section{Hosts}

Nearly all host plants are in the family Rosaceae and are listed by Drake and Ruhoff (1965). Firethorn is the most reported host in Florida, but loquat (Eriobotrya japonica Lindl.) occasionally suffers injury; and there are isolated reports on hawthorn (Crataegus sp.), wild crabapple (Malus coronaria 
(L.) Mill.), and flowering crabapple (Malus floribunda Sieb.) in northern Florida. Some of the hosts elsewhere in the U.S. include shadbush (Amelanchier spp.), hawthorns (Crataegus spp.), crabapples (Malus spp.), buttonbush (Cephalanthus occidentalis L.), Cotoneaster hupehensis Rehd. \& Wils., quince (Cydonia sp.), flowering quince (Chaenomeles sp.), pear (Pyrus sp.), and mountain ash (Sorbus spp.).

\section{Detection Notes}

1. Infested leaves show a whitish blotching or stipling on the upper surface. Similar stipling is caused by the southern red mite, Oligonychus ilicus (McG.), which feeds on the upper surface primarily; however, it does not stain the lower leaf surface.

2. Infested lower leaf surfaces have dark brown spots and stains of lace bug excrement and show loss of green color.

3. On lower surface of leaves look for the lace bug in any of its three life forms: egg, nymph, and adult.

- Eggs are smooth, whitish, glistening, semitransparent, ovoid in shape, and $0.3 \mathrm{~mm}$ long. The broad end is slightly inserted into the leaf. The upper end of the egg is truncate and has a brown covering. Comstock (1880) reported that the eggs are sometimes confused with certain forms of fungi such as Phoma sp., or with certain kinds of homopterous galls.

- Nymphs are mostly shiny brown, broadly oval, flat and spiny.

- Adults are delicate, lace-like, with a double crossbar pattern of brown on the elytra.

\section{Management}

For management information, see the Insect Management Guide for Ornamentals

(

http://edis.ifas.ufl.edu/

TOPIC_GUIDE_IG_Ornamentals).

\section{Selected References}

Bailey, N.S. 1951. The Tingoidea of New England and their biology. Ent. Amer. 31 (N.S.): 1-140.

Bailey, N.S. 1960. Additions to the bioecology of the New England Tingidae and Piesmidae (Heteroptera). Psyche 66: 63-69.

Blatchley, W.S. 1926. Heteroptera or true bugs of eastern North America, with especial reference to faunas of Indiana and Florida. Nature Publishing Co., Indianapolis. $1116 \mathrm{p}$.

Comstock, J.H. 1880. The hawthorn tingis (Corythucha arcuata, Say, var.), order Hemiptera; family Tingidae. USDA, Report of the Entomologist for 1879: 221-222.

Drake, C.J., and F.A. Ruhoff. 1965. Lacebugs of the world (Hemiptera: Tingidae). 54-E 243: 1-634.

Feldman, A.E., and N.S. Bailey. 1953. The taxonomic value of the ovipositor in the New England species of the genus Corythucha Stål (Hemiptera: Tingidae). Psyche 59: 96-104.

Fitch, A. 1861. The quince tingis. Country Gentleman 17: 114.

Gibson, E.H. 1918. The genus Corythucha Stål (Tingidae: Heteroptera). 51-A 44: 60-104.

Koehler, P.G., D.E.Short and T.R. Fasulo. (1998). Pests In and Around the Home. UF/IFAS, SW-126.

Mizell, R.F., D.E. Short and T.R. Fasulo. (May 1998) WoodyPest. UF/IFAS. http://woodypest.ifas.ufl.edu/ (May 1999).

Morrill, A.W. 1903. Notes on the immature stages of some tingitids of the genus Corythucha. Psyche 10: 127-134.

Sailer, R.I. 1945. The bite of a lacebug, Corythucha cydoniae (Fitch). J. Kansas Ent. Soc. 18: 1.

Scott, H.E. 1960. Lace bugs and their control. North Carolina Agr. Ext. Serv. Folder 177 (n.p.). 
Short, D.E., R.F. Mizell, and T.R. Fasulo.

(1998). Woodybug: A knowledgebase of pest and beneficial arthropods of Florida woody ornamentals.

UF/IFAS. SW-119. 